\title{
Land Use and Climate Change Impacts on Flow Rate and Non-point pollution sources in Drinking Water Basins: Namazgah Dam Basin
}

\author{
ayfer özdemir ${ }^{1}$, Nusret Karakaya ${ }^{2}$, Abdullah Altuntaş ${ }^{3}$, and Azize KOÇ ${ }^{3}$ \\ ${ }^{1}$ The Ministry of Agriculture and Forestry, Turkey \\ ${ }^{2}$ Abant İzzet Baysal Üniversitesi Mühendislik ve Mimarlık Fakültesi \\ 3
}

January 27, 2022

\begin{abstract}
Successful water resource planning and management can be ensured by understanding the hydrological response of watersheds and non-point pollutions to land use/land cover and climatic changes. This study aims to present the effects of climate and land-use changes on hydrological processes and NPS pollutions to help prepare accurate water management policies based on their impacts. In this study, the Soil and Water Assessment Tool (SWAT) was applied to predict climate and land-use impacts on flow rate and non-point pollutions (NPS) in Namazgah Dam Basin in Turkey. Two different climate change scenarios, RCP 4.5 and RCP 8.5, and land-use scenarios, conversion of shrubland to forest and conversion of agricultural areas to the forest, were used, and statistical analyses were utilized to assess the results. At the end of this study, it was predicted that there would be an increase in phosphorus and nitrate loads and a decrease in streamflow rate.
\end{abstract}

\section{Introduction}

Sustainable water management in basins that supply drinking water requirements has been provided by applying protection management strategies about water quantity and quality. Anthropogenic activities such as agricultural, industrial, settlements have been tried to be under control by domestic legislations implemented by countries in their drinking water basins since these activities have threatened water quality and quantity. In Turkey, sustainable water management in drinking water basins has been ensured by the protective regulations surrounding the Regulation on Protection of Drinking and Utility Water Basins (PDUWB 2017). The legislation includes measures about land-use practices such as agricultural activities to take under control point and non-point pollution sources in basins. Although point pollution loads are easy to keep under control, it is not easy to keep the non-point source (NPS) loads under control for water resources decision-makers because non-point source pollution loads contain many uncertainties (Chen et al. 2017; Wang et al. 2018). The primary source of water quality degradation is NPS pollution rather than point source pollution (Mi et al. 2015). However, the water management policies prepared based on the legislation don't cover land use/cover and climate change impacts on flow rate and NPS pollutants. Land use/cover and climate changes are the most important key factors that have effects on hydrological processes and NPS pollution loads in water resources (Wagner et al. 2017; Gashaw et al. 2018; Tamm et al. 2018; Zhan et al. 2020). Implementation of successful water resource planning and management is possible by understanding the hydrological response of watersheds to physical (land use) and climatic (precipitation and air temperature) changes (Vorosmarty et al. 2000; Anand et al. 2018). Although the 
"paired catchment" experimental method (Bosch and Hewlett 1982) and the time series analysis (Li et al. 2012) have been mainly used to assess the impacts of land-use change on water resources, hydrological models are the most popular method since it provides an integrated approach for the water resources management by studying the relationships between climate change, land-use/cover change, and the water cycle. The Soil and Water Assessment Tool (SWAT), a semi-distributed and physically-based watershed-scale hydrological model developed by Arnold et al. (1998), has been widely used among these models since SWAT calculates long-term impacts of land use, land management practices and buildup of pollutants with a continuous time model (Neitsch et al. 2005). SWAT has been applied to show the potential impact of land management scenarios and land-use/cover and climate change impacts on the hydrology to decide better management scenarios (Bouraoui et al. 2005; Mango et al. 2011; Shen et al. 2015; Abbaspour et al. 2015; Hajihosseini et al. 2019; Aboelnour et al. 2020).

This study aims to show the effects of climate and land-use/cover changes on hydrological processes and NPS pollutants to generate more accurate water management plans on land use measures in drinking water basins and help future water management planning. SWAT was carried out to predict climate and land-use impacts on flow rate and non-point pollutions (NPS). Two different climate change scenarios, RCP 4.5 and RCP 8.5, and land-use scenarios, conversion of shrubland to forest and conversion of agricultural areas to the forest, were used, and statistical analyses were utilized to assess the results. These impacts were shown on the Namazgah dam basin in Turkey to give an example of the application in the drinking water basin. The basin supplies drinking water to Kocaeli province in Turkey.

\section{Materials and Methods}

The method used in this study: (1) generating SWAT of the basin, (2) the model calibration by using the FACT (Fast Auto Calibration Tool; Ozdemir and Leloglu 2018) (3) examining the effects on climate change water resources in the basin by using the Representative Concentration Pathways, RCP 4.5, and RCP 8.5 climate change scenarios, (4) predicting the effects of climate change on streamflow rate and NPS pollution loads by using different land-use scenarios; conversion of shrubland to the forest, conversion of agricultural areas to the forest, and (5) the assessment of the results by using statistical analysis (6) determining the effects of climate and land-use changes on water resources in the basin to provide further research on the subject in the future.

\section{Study Area}

The Namazgah dam is between $40^{0} 55^{\prime}-41^{0} 04^{\prime}$ north longitude and $30^{0} 00^{\prime}-30^{0} 25^{\prime}$ east latitude in the Marmara region, Turkey (Fig. 1). The dam was constructed on the Namazgah river to provide water demands such as irrigation, drinking, etc., of villages and towns of Izmit and Korfez districts and tourist settlements at the Black Sea coast. The area of the basin is $100.64 \mathrm{~km}^{2}$. The land in the basin is predominantly used for agriculture activities, especially for hazelnut production and pasture in the basin. The recorded mean annual rainfall, evaporation, maximum and minimum temperature values are $805 \mathrm{~mm} / \mathrm{a}, 744.3 \mathrm{~mm} / \mathrm{a}, 25^{0} \mathrm{C}$ and $5{ }^{0} \mathrm{C}$, respectively. The mean annual flow rate of the Namazgah river is measured as $48.88 \mathrm{hm}^{3}$. The planning amount of water to be supplied as drinking and domestic water from the Namazgah Dam of 2014, 2030 , and 2045 is $8.695 .399,11.300 .658$, and $12.965 .044 \mathrm{~m}^{3} /$ year, respectively.

\section{SWAT}

The primary elements of the SWAT model are weather, hydrology, soil temperature and properties, plant growth, nutrients, pesticides, bacteria and pathogens and land management. In SWAT, sub-basins are generated by dividing the basin based on the topography. Hydrologic response units (HRUs) for each sub-basin, the smallest unit in the model, are created from equivalent combinations of land use and soil type. The calculation of hydrologic processes is made at the HRU level and happens in two steps: (1) 
calculating flow and sediment, nutrients, bacteria, and pesticides loads at each HRUs, and then combining area-weighted HRU-level loadings to the sub-basin level; and (2) routing loadings from each sub-basin through the channel/stream network (Gassman et al. 2007).

\section{FACT}

A software package called Fast Automatic Calibration Tool (FACT) was developed for SWAT to increase the calibration performance (Özdemir and Leloglu 2018). The optimization method applied to the FACT is the Sequential Uncertainty Conformity Algorithm (SUFI-2) since a large number of parameters in conjunction with uncertainty analysis can be performed by this algorithm. The FACT was developed to reduce some drawbacks of SUFI2 in SWAT-CUP which are the time consumption, user interaction requirement, and update problems of SWAT model files (Özdemir and Leloglu 2018). The FACT was applied by using 16 important parameters that reflect relevant processes of the system such as surface runoff, baseflow, lateral flow (Table 1). The stream gauge station on the Namazgah river was used to compare observed and measured flow rates. Since the observed flow rate values at the station were between 1991 and 2007, the model was performed between these years. The station has stayed under dam waters since 2007 , so no measurements are available.

\section{Data preparation}

The data prepared for the model are divided into two different types, time series and spatial inputs. The hydrologic cycle of the basin is simulated in daily and monthly time steps by the model. Meteorological data sets, minimum and maximum temperatures, rainfall, average relative humidity, average wind speed, average solar radiation, are used as time series type inputs whereas land use and soil layers are spatial data type inputs. Daily time steps were used in this study.

\section{The Digital Elevation Model}

The Digital Elevation Model (DEM) of the Namazgah dam basin was produced from 1:25 000 scale topographic maps. The resolution of DEM is $30^{*} 30$ meters. Universal Transverse Mercator (UTM) projection system and WGS_1984_35 N geographic coordinate were used in DEM. SWAT calculated minimum, maximum, mean and standard deviation elevation values which were 40, 350, 165.437 and 53.72, respectively. After preprocessing of DEM, minimum, maximum, and suggested sub-basin areas were calculated as 52, 10340, and 1000 in hectares, respectively. Based on streams and animal husbandry locations in the basin, 50 sub-basins outlets were defined (Fig. 1).

\section{Soil map}

SWAT model calculates hydrological processes in the basin using the physical and chemical properties of the soil. The most important of these features are; soil water availability capacity, hydraulic conductivity, organic carbon content, soil texture (sand, clay and gravel content) and thickness. Unfortunately, the soil map produced by the former Ministry of Food, Agriculture and Livestock (Oakes 1958) does not include these properties. It only includes Great Soil Groups and combination of soil properties, slope-depth, drainagetexture, drainage-salt-alkali combinations. The legend of the map is presented in the following: 


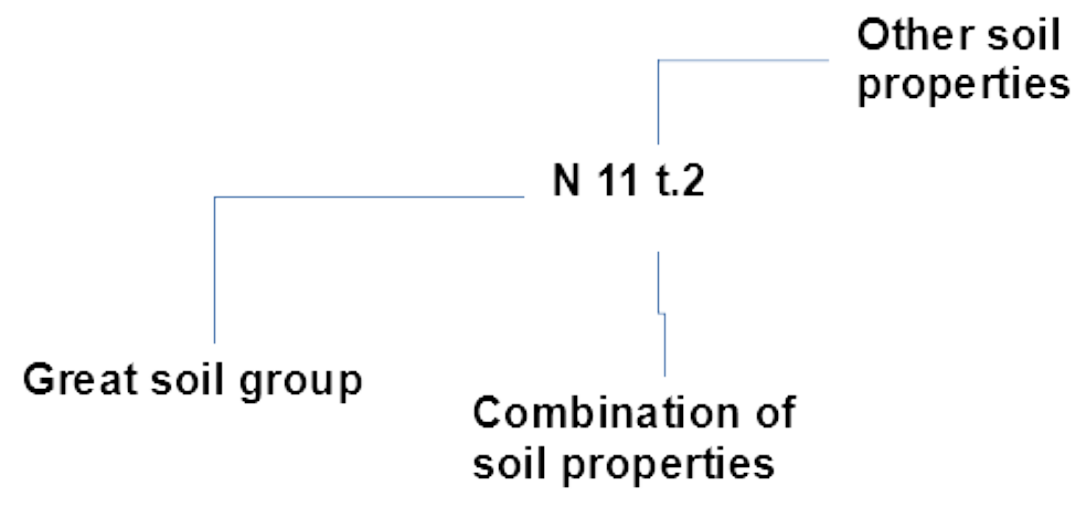

Based on Great Soil Group and combination of soil properties, soil depth is defined. After having on the Great Soil Group and depth, percentage of clay, sand and silt amount are defined according to determination soil properties study of Ardas and Creutberg (1995) in Turkey. Soil texture is determined by using soil texture triangle (Ley et al. 1994). The USLE equation soil erodibility (K) factor (USLE_K) was established with respect to the soil textures. The value of USLE_K is between 0.1 and 0 . A value of $<0.02$ shows a soil of low erodibility; $0.02-0.04$ shows moderate erodibility; and $>0.04$ shows high erodibility. When the silt content of soil type increases, it can become more erodible regardless of whether there is a comparable reduction in the sand or clay fraction (Rosewell 1993). The soil bulk density (SOL_BD) values employed in SWAT database are defined based on soil texture groups by using Guides for Editing Soil Properties (2005). The soil available water capacity (SOL AWC) has been defined by using soil texture groups, as described in Ley et al. (1994). The soil hydraulic conductivity (SOL_K) has been determined based on soil texture group, as suggested by Guidelines for Soil Description (Jahn et al. 2006) (Fig. 1c). After these processes, SWAT-relevant soil database of the basin was generated.

\section{Landuse/landcover}

Three different data, land-use/ land cover map produced by Kocaeli Buyuksehir Municipality, crop cultivation data of Kocaeli Provincial Directorate of Agriculture, land-use/ land cover created by the Ministry of Agriculture and Forestry within the framework of the STATIP project, were used to generate the land-use/ land cover map of the study area due to having some challenges about these data such as definitions of land use/land cover, lack of crop pattern, etc. The project data map was generated by using SPOT satellite data with 5 and 2.5-meter resolution on the 1/25000 topographic map. Although the spatial resolution of STATIP project land use/landcover map is good, the definition of absolute irrigated agricultural areas, dry absolute agricultural areas, marginal irrigated agricultural areas and dry marginal agricultural areas cause confusion about agricultural products in the basin. These definitions were made based on the framework of the Regulation on the Conservation, Use and Planning of Agricultural Lands (Official Gazette 2017 no: 30265). Marginal agricultural land means private croplands and planted lands where traditional tillage agriculture cannot be carried out due to soil and topographic limitations. "Absolute" agricultural land means that the land is currently suitable for agricultural production in terms of the physical, chemical, and biological properties of the soil, non-limiting, no or very little topographic restrictions. In addition, irrigated agricultural land is defined as that the land where additional water needed by the cultivated plants during the growing phase. Although land-use/land cover map produced by Kocaeli Buyuksehir Municipality includes just hazelnut and agricultural areas, there is no specific definition about crop production in the agricultural areas. Crop cultivation data of Kocaeli Provincial Directorate of Agriculture is represented by points instead of areas based on villages in the basin as ton/year production. Thus, the land-use/cover map was produced by combining these data in GIS (Geographic Information System) (Fig. 2). Based on the produced map, there are mostly wheat and evergreen broadleaf forest areas. Hazelnuts are not in SWAT database, so these crops are defined as shrubland since hazelnut is in the shrubland flora. 


\section{Meteorological data}

NCEP/CFSR (The National Centers for Environmental Prediction/Climate Forecast System Reanalysis) data were used to obtain meteorological data of the study area. These data have advantage that they come along with in situ measurements from several ground stations. Meteorological data handled from the station near the study area is between 1979 and 2014 years in the daily time step.

\section{Pollution Sources}

There are 3768 sheep and 3006 dairy cattle in the Namazgah Dam basin based on TUIK data that was obtained from villages in the basin (Fig. 3). The amount of manure caused by poultry, cattle, and sheep were calculated using coefficients used for animal pollution loads as suggested by Uttormark et al. (1974). Animal-based fertilizer calculations were made for villages for three different animal categories: poultry, cattle, and sheep. The average coefficients for cattle were determined for beef and dairy cattle to calculate manure since cattle are not divided into precisely beef and dairy cattle in the basin.

Wheat cultivation is carried out in many different soil types. The $\mathrm{pH}$ of the soil is very important in terms of plant nutrition and fertilization. The best development environment for wheat plants is in soils with neutral $\mathrm{pH}$ (6.6-7.3). In addition, one of the most significant factors affecting wheat yield is the amount of precipitation and the distribution of precipitation during the growing period. Thus, the amount of nitrogen fertilizer per decare (da) during the development period of the wheat should be given based on these factors. Top fertilization in wheat cultivation is carried out in October or before and in the spring. $26 \mathrm{~kg} / \mathrm{da}$ nitrogen, $8.5 \mathrm{~kg} / \mathrm{da}$ phosphorus, and 0.96 potassium $\mathrm{kg} / \mathrm{da}$ are given in October or before to make balanced fertilization in wheat and barley cultivation in the basin. Fertilization for the hazelnut cultivation is carried out as 2.7 $\mathrm{kg} / \mathrm{m}^{2}$ nitrogen, $0.8 \mathrm{~kg} / \mathrm{m}^{2}$ phosphorus and 0.09 potassium $\mathrm{kg} / \mathrm{m}^{2}$ on March. The fertilizer amount applied to each crop in the basin was determined by considering the Kocaeli Agriculture Provincial Directorate Fertilizer guideline.

\section{Results}

\section{Hydrologic Model}

SWAT calculates hydrological processes based on HRUs in each sub-basin in the basin. HRUs were produced by the unique combination of soil, land use, and slope in each sub-basin. After the physical and chemical parameters of the soil, land use characteristics, pollution sources and management processes of the basin were defined in the model, together with the climate data, the model was simulated between 1991-2007, after 3 -years warming period, using the monthly time step in the model. Asymmetric distribution was used for precipitation distribution, and SCS (Soil Conservation Service) method was used for surface runoff (USDA 1986). Bagnold method (Bagnold 1966) was applied for the sediment transport. The results of the simulated flow rate were compared to the values of the stream gauge station on the Namazgah river results of the model. Model accuracy was determined based on Nash-Sutcliffe efficiency (NSE), and coefficient determination $\left(\mathrm{R}^{2}\right)$. According to the comparison between simulated and observed discharge values on the stream gauge station on the Namazgah river, NSE, and R2 are 0.48 and 0.58 . Although the accuracy values of the model indicate that the model did not reflect the real world enough, the graphical comparison of the flow rate between 1991 and 2007 shows that features of the simulated flow rate are similar to observed flow rates.

While the 1991-2002 period was used for the calibration of the model, the 2003-2007 period was used for the validation. The initial model run had $\mathrm{r}^{2}=0.58, \mathrm{NS}=0.48$ improved to $\mathrm{r}^{2}=0.63, \mathrm{NS}=0.56$, after the calibration by using the FACT with 200 simulation numbers. The model run had $\mathrm{r}^{2}=0.80$, NS $=0.68$ after the validation (Fig. 4). The accuracy of the model results is good based on Moriasi et al. (2007) model performance assessment. Unfortunately, there is no monitoring station for water quality assessment on the Namazgah river. So, the model accuracy assessment in terms of water quality measurements couldn't be 
made. However, SWAT is the most popular model since ungauged watersheds can be modelled accurately by SWAT (Gassman et al. 2014). Moreover, SWAT simulates long-term impacts of land use, land management practices and buildup of pollutants with a continuous time model (Neitsch et al. 2005).

\section{Climate Change Impacts}

The General Directorate of Meteorology has developed climate projections for the 2016-2099 period using HadGEM2-ES, MPI-ESM-MR, GFDL-ESM2M global model data sets in order to reveal how climate change will affect Turkey in the future. In this study, global model data sets RegCM4.3.4 regional model and dynamic scale-down method, according to the RCP 4.5 and RCP 8.5 scenarios, the results of the projection of $20 \mathrm{~km}$ resolution with 1971-2000 reference period 2016-2040, 2041-2070, 2071-2099 future periods were obtained. Climate change data obtained from the study of the General Directorate of Meteorology was used to show the effects of climate change on the flow rates and NPS pollution loads in the Namazgah dam basin.

According to the Fifth Assessment Report of the Intergovernmental Panel on Climate Change (IPCC 2014), Representative Concentration Pathways are new scenarios considering global greenhouse gas and aerosol concentrations and alternative future scenarios (SRES) as a prelude. There are four RCPs defined as 2.5, 4.5, 6.0 and 8.5 depending on the total radiative forcing path and level until 2100. In this study, RCP 4.5 (540 ppm $\mathrm{CO} 2$ ) and RCP 8.5 (940 ppm CO2) scenarios were selected to reveal the effects of future climate projections on the Namazgah dam basin. While RCP 4.5 assumes a long-term level of medium greenhouse gas concentrations with broadly pre-defined strain stabilization constraints, RCP 8.5 acknowledges that greenhouse gas emissions will increase over time in the 21st century and approach very high levels by 2100 (IPCC 2014). According to the RCP 4.5 and RCP 8.5 scenarios, the estimated monthly mean total precipitation and changes in average temperature for the years 2021-2090 were compared with the measurements of the meteorological station in the basin between 1979-2014. A decrease in the monthly average total amount of precipitation is estimated between 2021-2090. Although more rainfall was observed in autumn and spring between 1979 and 2014, the highest rainfall is expected in the summer period in 2022-2090 (Fig. 5a). An increase of approximately $0.49^{\circ} \mathrm{C}$ is expected in average monthly temperatures $2021-2090$ compared to 1979-2014 concerning the RCP 8.5 scenario, while a decrease of $0.35{ }^{\circ} \mathrm{C}$ is expected concerning the RCP 4.5 scenario (Fig. 5b).

After the hydrological model was run for 2021-2099 according to the RCP 4.5 and RCP 8.5 scenarios, the effect of climate change on flow rate and NPS pollution loads was shown. Mean flow rate values according to RCP 8.5 and RCP 4.5 scenarios, respectively; It is estimated at 0.67 and $0.68 \mathrm{~m}^{3} / \mathrm{sec}$. When predicted flow rate values based on RCP 4.5 and RCP 8.5 were examined for 2022-2047, 2048-2072, and 2073-2099 periods, $0.64,0.70 ; 0.71,0.68$, and $0.80,0.64, \mathrm{~m}^{3} / \mathrm{sec}$, respectively were predicted. TN values based on RCP 4.5 and RCP 8.5 for 2022-2047, 2048-2072, and 2073-2099 periods changes 43947.02, 48987.89; 50653.91, 46405.73, and 54913.97, 46246.08, respectively. TP values based on RCP 4.5 and RCP 8.5 for 2022-2047, 2048-2072, and 2073-2099 periods varies $11474.19,13808.91 ; 13943.31,11959.92$, and $14174.19,12035.26$, respectively (Fig. 6, Table 2).

\section{Scenario Analysis}

Land-use scenarios were developed and explored to understand the sensitivity of model outputs to understand the impact of land-use/cover changes on the flow rates and NPS pollution loads of the Namazgah river. The land-use scenarios were chosen according to the Regulation on Protection of Drinking and Utility Water Basins (PDUWB 2017). Forest areas are protected and enhanced, the current agricultural areas are protected and it isn't permitted to increase their areas. Thus, based on the regulation, two different scenarios were chosen to observe land use changes impacts on water quantity and quality, which are; conversion of shrubland to the forest and, conversion of agricultural areas to the forest

\section{conversion of shrubland to forest}

Examining the impacts of the conversion of shrubland to forest areas shows that mean flow rate values 
according to RCP 4.5 and RCP 8.5 scenarios were estimated as 0.8 and $0.67 \mathrm{~m}^{3} / \mathrm{sec}$, respectively. Predicted flow rate values based on RCP 4.5 and RCP 8.5 for 2022-2047, 2048-2072, and 2073-2099 periods were 0.72, $0.79 ; 0.79,0.77$; and $0.87,0.73 \mathrm{~m}^{3} / \mathrm{sec}$, respectively. TN values based on RCP 4.5 and RCP 8.5 for 2022-2047, 2048-2072, and 2073-2099 periods changes $75200.2,83661.618 ; 106754,112049.514$, and 125218, 104668.712, respectively. TP values based on RCP 4.5 and RCP 8.5 for 2022-2047, 2048-2072, and 2073-2099 periods varies $13562.3,16497.508 ; 15897.7,14410.515 ; 15750.6,14627.425$, respectively (Fig. 7 , table 2).

\section{conversion of agricultural areas to forest}

According to the RCP 4.5 and RCP 8.5 scenarios, the average flow rates were estimated as 0.51 and 0.77 $\mathrm{m}^{3} / \mathrm{sec}$, respectively, based on this scenario. Estimated flow rate values based on RCP 4.5 and RCP 8.5 were examined for 2022-2047, 2048-2072, and 2073-2099 periods, 0.727, 0.5298; 0.798, 0.504, and 0.876, 0.48 $\mathrm{m} 3 / \mathrm{sec}$ were predicted, respectively. TN values based on RCP 4.5 and RCP 8.5 for 2022-2047, 2048-2072, and 2073-2099 periods changes $75200.2,36282.471 ; 106754,32743.9884$ and $125218,32592.5749$, respectively. TP values based on RCP 4.5 and RCP 8.5 for 2022-2047, 2048-2072, and 2073-2099 periods varies 13562.3, 12034.256; 15897.7, 10499.158, and 15750.6, 10543.612, respectively (Fig. 8, table 2).

\section{Statistical Assessment of Model Results and Scenario Analyses}

Descriptive statistics of the results obtained from the modeling studies are presented in Table 3. Considering two climate scenarios and two land use scenarios, TN load, TP load and Q Tukey HSD were compared using multiple benchmarks. Statistical significance level of two and higher interaction terms was determined using full factorial design analysis of variance (ANOVA). LSM values (which can also be defined as adjusted means) are values predicted by the model for certain level combinations of categorical variables when all other model factors are set to neutral values. This approach was chosen due to unequal sample sizes (Table $4)$.

According to the Tukey HSD multiple comparison test, it was concluded that there would be no significant change in the TP load in the future depending on the climate and land use scenarios. On the other hand, it is estimated that there may be significant changes in $\mathrm{TN}$ load and Q between some scenarios. There is no significant difference between S1, S4 and S5 scenarios in terms of TN load. Again, it is estimated that there will be no difference between S2, S3 and S6 scenarios in terms of TN load. On the other hand, it is expected that there will be a significant difference between scenarios S1, S4 and S5 and scenarios S2, S3 and S6. In terms of flow rate $(\mathrm{Q})$, a significant difference is expected between the S5 scenario and other scenarios. On the other hand, it is predicted that there will be no significant difference between scenarios S1, S2, S3, S4 and S6.

The changes that may occur in TN, TP and Q depending on the climate and land use scenarios were also compared with the data of the previous period (1991-2007) by using Dunnet's test (Table 5). Depending on the climate and land use scenarios, when the 2022-2099 period is compared with the 1991-2007 period, it is estimated that there will be an increase in phosphorus loads and a decrease in stream flow rate. On the other hand, it is expected that the TN load will decrease only in the S5 scenario and increase in all other scenarios. When evaluated together with the data presented in Table 5, the changes that may occur in the TP load in all scenarios will not be significant when compared to S0. On the other hand, the change that may occur when compared with the flow rate of all scenarios will be statistically significant. In terms of TN load, the difference between S0 and S1, S4, S5 scenarios is statistically insignificant, whereas the difference between S0 and S2, S3 and S6 scenarios will be significant.

\section{Discussion}

IPCC (2018) indicated that global warming was predicted to increase by $1.5{ }^{\circ} \mathrm{C}$ by 2050 's compared with the present situation. Hydrological cycle and water quality will be affected by global warming (Anand et 
al. 2018). The generation of proper water management plans depends on interdisciplinary approaches and modeling studies of direct and indirect effects of climate change on drinking water resources (Qiu et al. 2019). Water management strategies for drinking water basins must be developed based on climate change's effect on water quality and quantity (Garnier and Holman 2019). It is difficult to meet good quality water demand for public health since the world population until 2050 will increase 9,7 million, so this will increase world water demand by 20-30\% (UNESCO, 2019). Land uses-covers and climate change are the main factors of water quality and quantity degradation globally (Giri and Qiu 2016; Su et al. 2016). The preparation of better water management policies is based on both land use-cover and climate change impacts on non-point pollution sources and streamflow (Mello et al. 2018). Although domestic legislation has been conducted to provide sustainable drinking water management in many countries, measures in that legislation haven't been determined based on adaptation to climate change and for understanding the patterns of water use under different land-use/cover policies (Wang et al. 2018; Clerici et al. 2019; Trolle et al. 2019). In Turkey, based on the Regulation on Protection of Drinking and Utility Water Basins (PDUWB 2017), site-specific drinking water management plans have been generated. However, these studies don't include climate and land usecover change policies. Moreover, although these studies cover many measures, especially the restriction of agricultural activities and protection of forest areas, the effects of these measures on streamflow and NPS have not been examined. This study is an example of land-use/cover and climate change effects on streamflow and NPS to generate accurate water resources management. Climate change scenarios, RCP 4.5 and RCP 8.5, and land-use scenarios, conversion of shrubland to the forest and conversion of agricultural areas to the forest, were combined to show their impacts on flow rate and NPS pollutants to generate future proper water management plans. Study results show that conversion of agricultural areas to the forest under RCP 8.5 has more impacts on streamflow and NPS pollutants. This situation indicates that land-use planning and restrictions in drinking water basins require examining land-use/cover and climate change effects on water resources and NPS pollutants to protect drinking water resources for public human health.

Moreover, this study also shows that modeling studies and statistical assessments of modeling results are important to evaluate these effects while studying these effects on water resources and NPS pollutants since combining modeling and statistical assessments give whether or no significant effects of these changes.

\section{Conclusion}

The protective regulations in drinking water basins in Turkey have tried to provide sustainable water management. However, water management policies prepared based on the legislation don't contain land use-landcover and climate change impacts on flow rate and NPS pollutants. The main source of water quality degradation is NPS pollutions rather than point source pollution. This study presents the preliminary results to determine the impact of land use and climate change on streamflow rate and NPS pollutants in the Namazgah dam basin to develop successful sustainable watershed management plans. According to the RCP 4.5 and RCP 8.5 scenarios, a decrease in the monthly average total amount of precipitation is estimated between 2021-2090. The highest rainfall is expected in the summer period in 2022-2090 in contrast to between 1979 and 2014. An increase of approximately $0.49^{\circ} \mathrm{C}$ is expected in average monthly temperatures 2021-2090 compared to 1979-2014 concerning the RCP 8.5 scenario, while a decrease of $0.35{ }^{\circ} \mathrm{C}$ is expected concerning the RCP 4.5 scenario. Corresponding modeled stream flow rates based on RCP 4.5 and RCP 8.5 scenarios for 2021-2099 period, are 0.716 and $0.672 \mathrm{~m}^{3} / \mathrm{sec}$, respectively. These values show significant decrease in flow rates of the Namazgah river in the future (the mean annual flow rate was $1.90 \mathrm{~m}^{3} / \mathrm{sec}$ between 1991-2007). The amount of the monthly average of TN and TP loads in the basin for the years 1991-2007 were 41379.953 and 8427.269 $\mathrm{kg}$, respectively. However, these were predicted as $49892.916 \mathrm{TN}, 13200.190 \mathrm{TP} ; 47211.188 \mathrm{TN}, 12602.330$ TP kg based on RCP 4.5 and RCP 8.5 for 2021-2099 period. According to both climate change scenarios, a decrease in the predicted flow rates will cause an increase in TP and TN loads. When examining land-use change scenarios, according to RCP 4.5, similar results were obtained for both land-use change scenario. However, according to RCP 8.5, conversion of farmland to forest has more effect on an increase in NPS loads and a decrease in flow velocities than conversion of shrublands to the forest. 


\section{ACKNOWLEDGMENTS}

The author is grateful to the Republic of Turkey Ministry of Agriculture and Forestry General Directorate of Water Management and Kocaeli Metropolitan Municipality General Directorate of Kocaeli Water and Sewerage Administration (ISU) due to providing the data.

\section{DATA AVAILABILITY}

The data that support the findings of this study are available from the Republic of Turkey Ministry of Agriculture and Forestry General Directorate of Water Management and Kocaeli Metropolitan Municipality General Directorate of Kocaeli Water and Sewerage Administration (ISU). Data can be obtained from these Institutions with their permission.

\section{REFERENCES}

Abbaspour K.C., Rouholahnejad, E., Vaghefi, S., Srinivasan, R., Yang, H. \& Kløve, B. (2015). A continentalscale hydrology and water quality model for Europe: Calibration and uncertainty of a high-resolution largescale SWAT model. Journal of Hydrology, 524: 733-752.

Aboelnour, M., Gitau, M.W. \& Engel, B.A. (2020). A Comparison of Streamflow and Baseflow Responses to Land-Use Change and the Variation in Climate Parameters Using SWAT. Water, 12, 191.

Anand, J., Gosain, A. K., \& Khosa, R. (2018). Prediction of land use changes based on Land Change Modeler and attribution of changes in the water balance of Ganga basin to land use change using the SWAT model. Science of The Total Environment, 644, 503-519. doi:10.1016/j.scitotenv.2018.07.017

Ardas, S. \& Creutzberg, D. (1995). Soil Reference Profiles of Turkey. Dept. of Soil Science-Faculty of Agriculture-Çukurova University, International Soil Reference and Information Centre. Country Report 3.

Arnold, J. G., Srinivasan, R., Muttiah, R.S. \& Williams, J.R. (1998). Large area hydrologic modeling modeling and assessment, Part I: Model development. J. Am. Water Resour. Assoc., 34, 73-89.

Bouraoui, F., Benabdallah, S., Jrad, A. \& Bidoglio, G. (2005). Application of the SWAT model on the Medjerda river basin (Tunisia). Physics and Chemistry of the Earth, Parts A/B/C, 30(8-10), 497-507.

Bosch, J.M., Hewlett, J.D., 1982. A review of catchment experiments to determine the effect of vegetation changes on water yield and evapotranspiration. J. Hydrol. 55: 3-23. https://doi.org/10.1016/00221694(82)90117-2.

Clerici, N., Cote-Navarro, F., Escobedo, F.J., Rubiano, K., Villegas, J.C., 2019. Spatio-temporal and cumulative effects of land use-land cover and climate change on two ecosystem services in the Colombian Andes. Sci. Total Environ. 685, 1181-1192.

Fontes Júnior, R., \& Montenegro, A. (2019). Impact of Land Use Change on The Water Balance In A Representative Watershed In The Semiarid Of The State Of Pernambuco Using The Swat Model. Engenharia Agrícola, 39(1), 110-117. doi:10.1590/1809-4430-eng.agric.v39n1p110-117/2019.

Hajihosseini, M., Hajihosseini, H., Morid, S., Delavar,M. \& Booij, M.J. (2019). Impacts of land use changes and climate variability on transboundary Hirmand River using SWAT. Journal of Water and Climate Change, jwc2019100. doi: https://doi.org/10.2166/wcc.2019.100.

Gashaw, T., Tulu, T., Argaw, M., Worqlul, A.W., 2018. Modeling the hydrological impacts of land use/land cover changes in the Andassa watershed, Blue Nile Basin, Ethiopia. Sci. Total Environ. 619-620:1394-1408. https://doi.org/ 10.1016/j.scitotenv.2017.11.191. 
Garnier, M. and Holman, I. (2019) Critical Review of Adaptation Measures to Reduce the Vulnerability of European Drinking Water Resources to the Pressures of Climate Change.Environmental Management. doi:10.1007/s00267-019-01184-5

Gassman, P.W., Reyes, M.R., Green, C.H. \& Arnold, J.G. (2007). The soil and water assessment tool: historical development, applications, and future research directions. Trans. ASABE, 50 (4), 1211-1250.

Giri, S., Qiu, Z., 2016. Understanding the relationship of land uses and water quality in twenty first century: a review. J. Environ. Manag. 173, 41-48.

Jahn, R., Blume, H.P., Asio, V.B., Spaargaren, O. \& Schad, P. (2006). Guidelines for soil description. 4th ed. Rome: Food and Agriculture Organization of the United Nations, p. 67-77.

IPCC (2018) Summary for Policymakers. In: Masson-Delmotte, V, Zhai P, Pörtner HO, Roberts D, Skea J, Shukla PR, Pirani A, Moufouma-Okia W, Péan C, Pidcock R, Connors S, Matthews JBR, Chen Y, Zhou X, Gomis MI, Lonnoy E, Maycock M, Tignor M, Waterfield T (eds) Global Warming of $1.5^{\circ} \mathrm{C}$. An IPCC Special Report on the impacts of global warming of $1.5^{\circ} \mathrm{C}$ above pre-industrial levels and related global greenhouse gas emission pathways, in the context of strengthening the global response to the threat of climate change, sustainable development, and efforts to eradicate poverty.

Mango, L. M., Melesse, A. M., McClain, M. E., Gann, D. \& Setegn, S.G. (2011). Land use and climate change impacts on the hydrology of the upper Mara River Basin, Kenya: results of a modeling study to support better resource management. Hydrol. Earth Syst. Sci., 15, 2245-2258, https://doi.org/10.5194/hess-15-2245-2011.

Mello, K., Costa, D.R., Valente, R.A., Vettorazzi, C.A., 2018a. Multicriteria evaluation for protected area definition aiming at water quality improvement. Brazilian Journal of Forestry and Environment 25 (3), e20160134. https://doi.org/10.1590/2179- 8087.013416. Mello, K., Randhir, T.O., 2018. Diagnosis.

Moriasi, D. N., Arnold, J. G., Van Liew, M. W., Bingner, R. L., Harmel, R. D., Veith, T. L., 2007. Model Evaluation Guidelines for Systematic Quantification of Accuracy in Watershed Simulations. American Society of Agricultural and Biological Engineers, 50(3), 885-900.

Neitsch, S.L., Arnold, J.G., Kiniry, J.R. \& Williams, J.R. (2005). Soil and water assessment tool theoretical documentation, Version 2005, USDA.ARS Grassland, Soil and Water Research Laboratory, Temple, TX. Available at: <www.brc.tamus.edu/swat/ doc.html>

Osei, M. A., Amekudzi, L. K., Wemegah, D. D., Preko, K., Gyawu, E. S., \& Obiri-Danso, K. (2019). The impact of climate and land-use changes on the hydrological processes of Owabi catchment from SWAT analysis. Journal of Hydrology: Regional Studies, 25, 100620. doi:10.1016/j.ejrh.2019.100620

Shen, Z., Zhong, Y., Huang, Q. \& Chen, L. (2015). Identifying non-point source priority management areas in watersheds with multiple functional zones. Water Research, 68, 563-571.

$\mathrm{Su}, \mathrm{W}$., Ahern, J.F., Chang, C., 2016. Why should we pay attention to "inconsistent" land uses? A viewpoint on water quality. Landsc. Ecol. Eng . 12 (2), 247-254.

Tamm, O., Maasikamäe, S., Padari, A., \& Tamm, T. (2018). Modelling the effects of land use and climate change on the water resources in the eastern Baltic Sea region using the SWAT model. CATENA, 167, 78-89. doi:10.1016/j.catena.2018.04.029

Trolle, D., Nielsen, A., Andersen, H.E., Thodsen, H., Olesen, J.E., Børgesen, C.D., et al., 2019. Effects of changes in land use and climate on aquatic ecosystems: coupling of models and decomposition of uncertainties. Sci. Total Environ . 657, 627-633.

UNESCO, 2019. The United Nations World Water Development Report 2019: Leaving No One behind. UNESCO, Paris. Available in: https://www.unwater.org/publication s/world-water-development-report-2019/.

Qi, J., Li, S., Bourque, C. P.-A., Xing, Z., \& Meng, F.-R. (2018). Developing a decision support tool for assessing land use change and BMPs in ungauged watersheds based on decision rules provided by SWAT 
simulation. Hydrol. Earth Syst. Sci.,, 22(7), 3789-3806. doi:10.5194/hess-22-3789-2018

Qiu J, Shen Z, Leng G, Xie H, Hou X and Guoyuan, W. (2019) Impacts of climate change on watershed systems and potential adaptation through BMPs in a drinking water source area. Hydrol., 573, 123135.https://doi.org/10.1016/j.jhydrol.2019.03.074

Wang, Q., Liu, R., Men, C., Guo, L., \& Miao, Y. (2018). Effects of dynamic land use inputs on improvement of SWAT model performance and uncertainty analysis of outputs. Journal of Hydrology, 563, 874-886. doi:10.1016/j.jhydrol.2018.06.063.

Wagner, P.D., Bhallamudi, S.M., Narasimhan, B., Kumar, S., Fohrer, N., Fiener, P., 2017. Comparing the effects of dynamic versus static representations of land use change in hydrologic impact assessments. Environ. Model. Softw. https://doi.org/10.1016/j. envsoft.2017.06.023.

Vörösmarty, C.J., Green, P., Salisbury, J., Lammers, R.B., 2000. Global water resources: vulnerability from climate change and population growth. Science 289, 284-288.

Zhang, H., Wang, B., Li Liu, D., Zhang, M., Leslie, L. M., \& Yu, Q. (2020). Using an improved SWAT model to simulate hydrological responses to land use change: a case study of a catchment in tropical Australia. Journal of Hydrology, 124822. doi:10.1016/j.jhydrol.2020.124822

Table 1. Calibration parameters for hydrological processes

\begin{tabular}{|c|c|}
\hline Parameters & Definition \\
\hline r_ CN2.mgt & Initial SCS runoff curve number \\
\hline $\mathrm{r}^{--}$SOL AWC.sol & Available water capacity of the soil layer \\
\hline $\mathrm{r}^{--} \mathrm{SOL}^{-}$K.sol & Saturated hydraulic conductivity $(\mathrm{mm} / \mathrm{hr})$ \\
\hline $\mathrm{r}^{-} \mathrm{SOL}^{-}$BD.sol & Moist bulk density $\left(\mathrm{Mg} / \mathrm{m}^{3}\right.$ or $\left.\mathrm{g} / \mathrm{cm}^{3}\right)$ \\
\hline $\mathbf{a}_{-}^{-}$GWQ̄MN.gw & Threshold depth of water in the shallow aquifer required for return flow to occur $\left(\mathrm{mm} \mathrm{H}_{2} \mathrm{O}\right)$ \\
\hline a_-_GW_REVAP.gw & Groundwater "revap" coefficient \\
\hline $\mathbf{v}_{-}^{-}$REVAPMN.gw & Threshold depth of water in the shallow aquifer for "revap" or percolation to the deep aquifer \\
\hline $\mathrm{v}^{--}$ALPHA BF.gw & Baseflow alpha factor (days) \\
\hline$v^{--}$GW DELAY.gW & Groundwater delay time (days) \\
\hline v_ESCŌ.hru & Soil evaporation compensation factor. \\
\hline $\mathrm{v}^{--}$SFTMP.bsn & Snowfall temperature $\left({ }^{\circ} \mathrm{C}\right)$ \\
\hline $\mathrm{v}^{-}$SMTMP.bsn & Snowmelt base temperature $\left({ }^{\circ} \mathrm{C}\right)$ \\
\hline $\mathrm{v}_{-}$SMFMX.bsn & Melt factor for snow on June $21\left(\mathrm{~mm} \mathrm{H}_{2} \mathrm{O} /{ }^{\circ} \mathrm{C}\right.$-day $)$ \\
\hline v__SMFMN.bsn & Melt factor for snow on December $21\left(\mathrm{~mm} \mathrm{H}_{2} \mathrm{O} /{ }^{\circ} \mathrm{C}\right.$-day $)$ \\
\hline v TIMP.bsn & Snow pack temperature lag factor. \\
\hline v SURLAG.bsn & Surface runoff lag time. \\
\hline
\end{tabular}

Table 2. Results of climate and land-use changes impact on flow rates and pollution loads

\begin{tabular}{lllllllll}
\hline Climate Change & Years & Q-45 & TN_45 & TP_45 & Q-85 & TN_85 & TP_85 \\
\hline & $\mathbf{2 0 2 2 - 2 0 4 7}$ & 0.64 & 43947.02 & 11474.19 & 0.70 & 48987.89 & 13808.91 \\
& $\mathbf{2 0 4 8 - 2 0 7 2}$ & 0.71 & 50653.91 & 13943.31 & 0.68 & 46405.73 & 11959.92 \\
& $\mathbf{2 0 7 3 - 2 0 9 9}$ & 0.80 & 54913.97 & 14174.19 & 0.64 & 46246.08 & 12035.26 \\
Landuse Scenario & Years & $\mathbf{Q - 4 5}$ & $\mathbf{T N} \mathbf{4 5}$ & $\mathbf{T P} \mathbf{4 5}$ & $\mathbf{Q - 8 5}$ & $\mathbf{T N} \mathbf{8 5}$ & $\mathbf{T P} \mathbf{8 5}$ \\
SHRBtoFRST & $\mathbf{2 0 2 2 - 2 0 4 7}$ & 0.73 & 75200.24 & 13562.32 & 0.79 & 83661.62 & 16497.51 \\
& $\mathbf{2 0 4 8 - 2 0 7 2}$ & 0.80 & 106753.65 & 15897.70 & 0.78 & 112049.51 & 14410.51 \\
& $\mathbf{2 0 7 3 - 2 0 9 9}$ & 0.88 & 125218.38 & 15750.63 & 0.73 & 104668.71 & 14627.43 \\
Landuse Scenario & Years & $\mathbf{Q - 4 5}$ & $\mathbf{T N} \mathbf{4 5}$ & $\mathbf{T P} \mathbf{4 5}$ & $\mathbf{Q - 8 5}$ & $\mathbf{T N} \mathbf{8 5}$ & $\mathbf{T P} \mathbf{8 5}$ \\
AGRCtoFRST & $\mathbf{2 0 2 2 - 2 0 4 7}$ & 0.73 & 75200.24 & 13562.32 & 0.53 & 36282.47 & 12034.26
\end{tabular}




\begin{tabular}{lllllllll}
\hline Climate Change & Years & Q-45 & TN_45 & TP_45 & Q-85 & TN_85 & TP_85 \\
\hline & $\mathbf{2 0 4 8 - 2 0 7 2}$ & 0.80 & 106753.65 & 15897.70 & 0.50 & 32743.99 & 10499.16 \\
& $\mathbf{2 0 7 3 - 2 0 9 9}$ & 0.88 & 125218.38 & 15750.63 & 0.49 & 32592.57 & 10543.61 \\
\hline
\end{tabular}

Table 3. Descriptive statistics of model results (between 2022 and 2099)

\begin{tabular}{|c|c|c|c|}
\hline Scenario & Statistical variable & $\begin{array}{l}\text { TN } \\
\left(\text { kg year }^{-1}\right)\end{array}$ & $\begin{array}{l}\text { TP } \\
\left(\text { kg year }^{-1}\right)\end{array}$ \\
\hline \multirow[t]{4}{*}{$\mathrm{S} 1$ (Climate change, $\mathrm{RCP}_{-} 4.5$ ) } & Mean & 49893 & 13200 \\
\hline & Std. deviation & 40052 & 10665 \\
\hline & Minimum & 7242 & 1204 \\
\hline & Maximum & 270038 & 63118 \\
\hline \multirow[t]{4}{*}{ S2 (Climate change, $\mathrm{RCP}_{-} 8.5$ ) } & Mean & 102627 & 15068 \\
\hline & Std. deviation & 67311 & 11904 \\
\hline & Minimum & 17110 & 1846 \\
\hline & Maximum & 461918 & 72846 \\
\hline \multirow[t]{4}{*}{ S3 (Landuse Change Shrubland to Forest, RCP_4.5) } & Mean & 102627 & 15068 \\
\hline & Std. deviation & 67311 & 11904 \\
\hline & Minimum & 17110 & 1846 \\
\hline & Maximum & 461918 & 72846 \\
\hline \multirow[t]{4}{*}{ S4 (Landuse Change Shrubland to Forest, RCP_8.5) } & Mean & 47211 & 12602 \\
\hline & Std. deviation & 33340 & 8902 \\
\hline & Minimum & 3661 & 151 \\
\hline & Maximum & 162341 & 40438 \\
\hline \multirow[t]{4}{*}{ S5 (Landuse Change Agricultural areas to Forest, RCP_4.5) } & Mean & 33870 & 11026 \\
\hline & Std. deviation & 25049 & 7771 \\
\hline & Minimum & 2383 & 97 \\
\hline & Maximum & 111475 & 32255 \\
\hline \multirow[t]{4}{*}{ S6 (Landuse Change Agricultural areas to Forest, RCP_8.5) } & Mean & 100032 & 15181 \\
\hline & Std. deviation & 61234 & 10723 \\
\hline & Minimum & 12753 & 203 \\
\hline & Maximum & 308134 & 55669 \\
\hline
\end{tabular}

Table 4. Differences between TN load, TP load and flow rate according to ANOVA-Tukey HSD multiple comparison test (least squares mean \pm standard error kg year-1) depending on climate and land use change

\begin{tabular}{lllll}
\hline Scenario & $\mathbf{N}$ & $\begin{array}{l}\text { LSM TN } \\
\left(\text { kg year }^{-1}\right)\end{array}$ & $\begin{array}{l}\text { LSM TP } \\
\left(\text { kg year }^{-1}\right)\end{array}$ & $\begin{array}{l}\text { LSM Q } \\
\left(\mathbf{m}^{\mathbf{3}} \mathbf{s n}^{-1}\right)\end{array}$ \\
\hline S0* & 17 & $41379.95 \pm 12387.83^{\mathrm{b}}$ & $8427.27 \pm 2493.42^{\mathrm{a}}$ & $1.9030 \pm 0.083^{\mathrm{a}}$ \\
S1 & 78 & $49892.92 \pm 5783.26^{\mathrm{b}}$ & $13200.19 \pm 1164.05^{\mathrm{a}}$ & $0.7163 \pm 0.0389^{\mathrm{b}}$ \\
S2 & 78 & $102627.48 \pm 5783.26^{\mathrm{a}}$ & $15068.33 \pm 1164.05^{\mathrm{a}}$ & $0.8011 \pm 0.0389^{\mathrm{b}}$ \\
S3 & 78 & $102627.48 \pm 5783.26^{\mathrm{a}}$ & $15068.33 \pm 1164.05^{\mathrm{a}}$ & $0.8011 \pm 0.0389^{\mathrm{b}}$ \\
S4 & 78 & $47211.19 \pm 5783.26^{\mathrm{b}}$ & $12602.33 \pm 1164.05^{\mathrm{a}}$ & $0.6717 \pm 0.0389^{\mathrm{b}}$ \\
S5 & 78 & $33870.40 \pm 5783.26^{\mathrm{b}}$ & $11026.25 \pm 1164.05^{\mathrm{a}}$ & $0.5061 \pm 0.0389^{\mathrm{c}}$ \\
S6 & 78 & $100031.99 \pm 5783.26^{\mathrm{a}}$ & $15181.26 \pm 1164.05^{\mathrm{a}}$ & $0.7660 \pm 0.0389^{\mathrm{b}}$ \\
\hline
\end{tabular}

*between 1991-2007 
Table 5. Comparison of the changes that may occur in TN, TP and Q based on climate and land use scenarios according to Dunnett's test with the previous period (1991-2007)

\begin{tabular}{llllll}
\hline & Scenario & Differences from Control & Std. Error & Adjusted Lower 95\% & Adjusted Upper 9 \\
\hline TN $\left(\mathrm{kg} \mathrm{year}^{-1}\right)$ & $\mathrm{S} 1$ & 8513.0 & 13671.3 & -24324.8 & 41350.7 \\
& $\mathrm{~S} 2$ & 61247.5 & 13671.3 & 28409.8 & 94085.3 \\
& $\mathrm{~S} 3$ & 61247.5 & 13671.3 & 28409.8 & 94085.3 \\
& $\mathrm{~S} 4$ & 5831.2 & 13671.3 & -27006.5 & 38669.0 \\
& $\mathrm{~S} 5$ & -7509.5 & 13671.3 & -40347.3 & 25328.2 \\
& $\mathrm{~S} 6$ & 58652.0 & 13671.3 & 25814.3 & 91489.8 \\
$\mathrm{TP}\left(\mathrm{kg} \mathrm{year}^{-1}\right)$ & $\mathrm{S} 1$ & 4772.9 & 2751.8 & -1836.7 & 11382.5 \\
& $\mathrm{~S} 2$ & 6641.1 & 2751.8 & 31.48 & 13250.6 \\
& $\mathrm{~S} 3$ & 6641.1 & 2751.8 & 31.48 & 13250.6 \\
& $\mathrm{~S} 4$ & 4175.1 & 2751.8 & -2434.52 & 10784.6 \\
& $\mathrm{~S} 5$ & 2598.9 & 2751.8 & -4010.61 & 9208.6 \\
$\mathrm{Q}\left(\mathrm{m}^{3} \mathrm{sn}^{-1}\right)$ & $\mathrm{S} 6$ & 6753.9 & 2751.8 & 144.41 & -0.97 \\
& $\mathrm{~S} 2$ & -1.19 & 0.092 & -1.41 & -0.88 \\
& $\mathrm{~S} 3$ & -1.10 & 0.092 & -1.32 & -0.88 \\
& $\mathrm{~S} 4$ & -1.10 & 0.092 & -1.32 & -1.01 \\
& $\mathrm{~S} 5$ & -1.23 & 0.092 & -1.45 & -1.18 \\
& $\mathrm{~S} 6$ & -1.40 & 0.092 & -1.62 & -0.92 \\
\hline
\end{tabular}

\section{FIGURES}

Fig. 1 Study Area a) DEM b) soil map of the study area c) Definition of soil properties for the SWAT database

Fig. 2 The generation of land use/landcover map of the study area.

Fig. 3 Animal husbandries in the basin

Fig. 4 Model calibration results

Fig. 5 Climate Change results based on RCP 4.5 and RCP 8.5

Fig. 6 Impacts of climate change on flow rates and pollution loads

Fig. 7 Impacts of conversion of shrubland to forest with climate change on flow rates and pollution loads

Fig. 8 Impacts of conversion of agricultural areas to forest with climate change on flow rates and pollution loads 


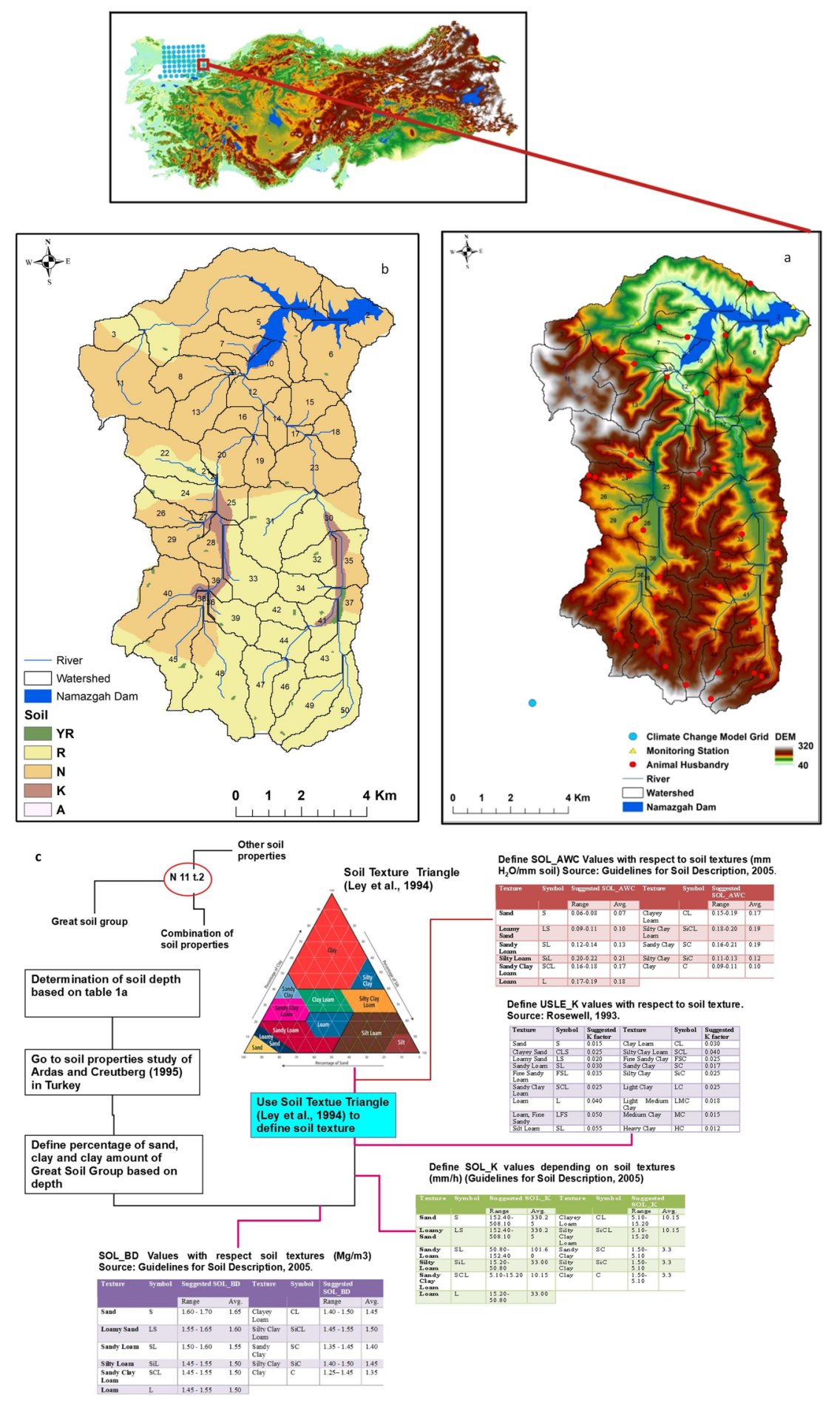



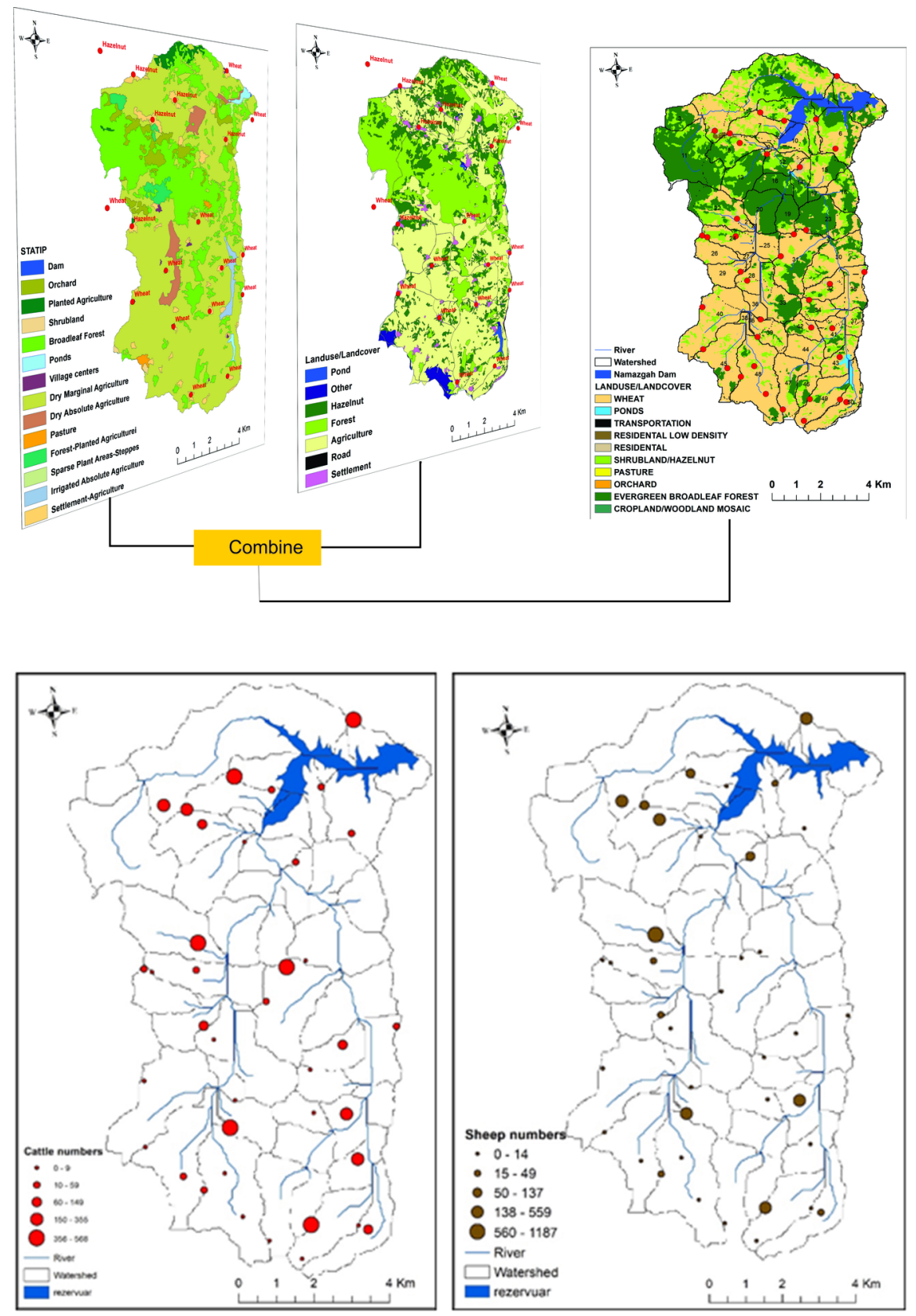

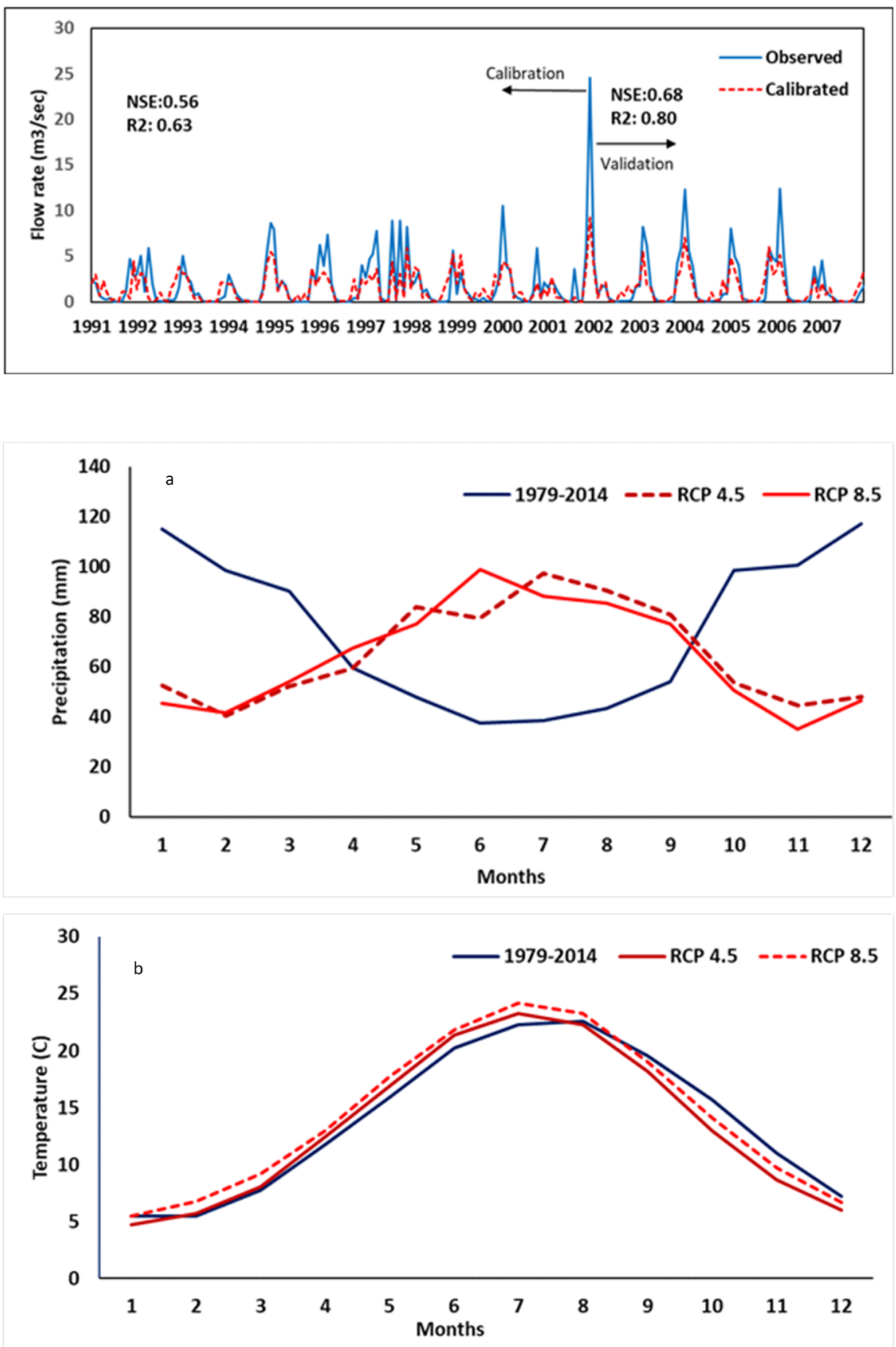


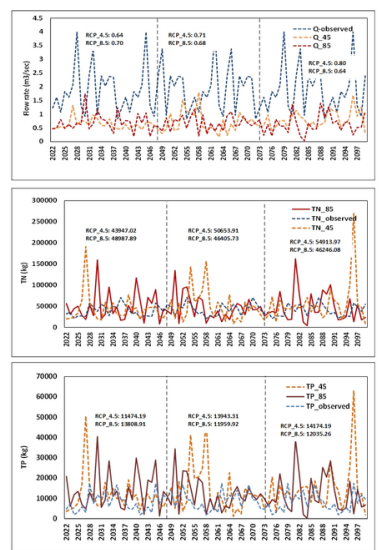



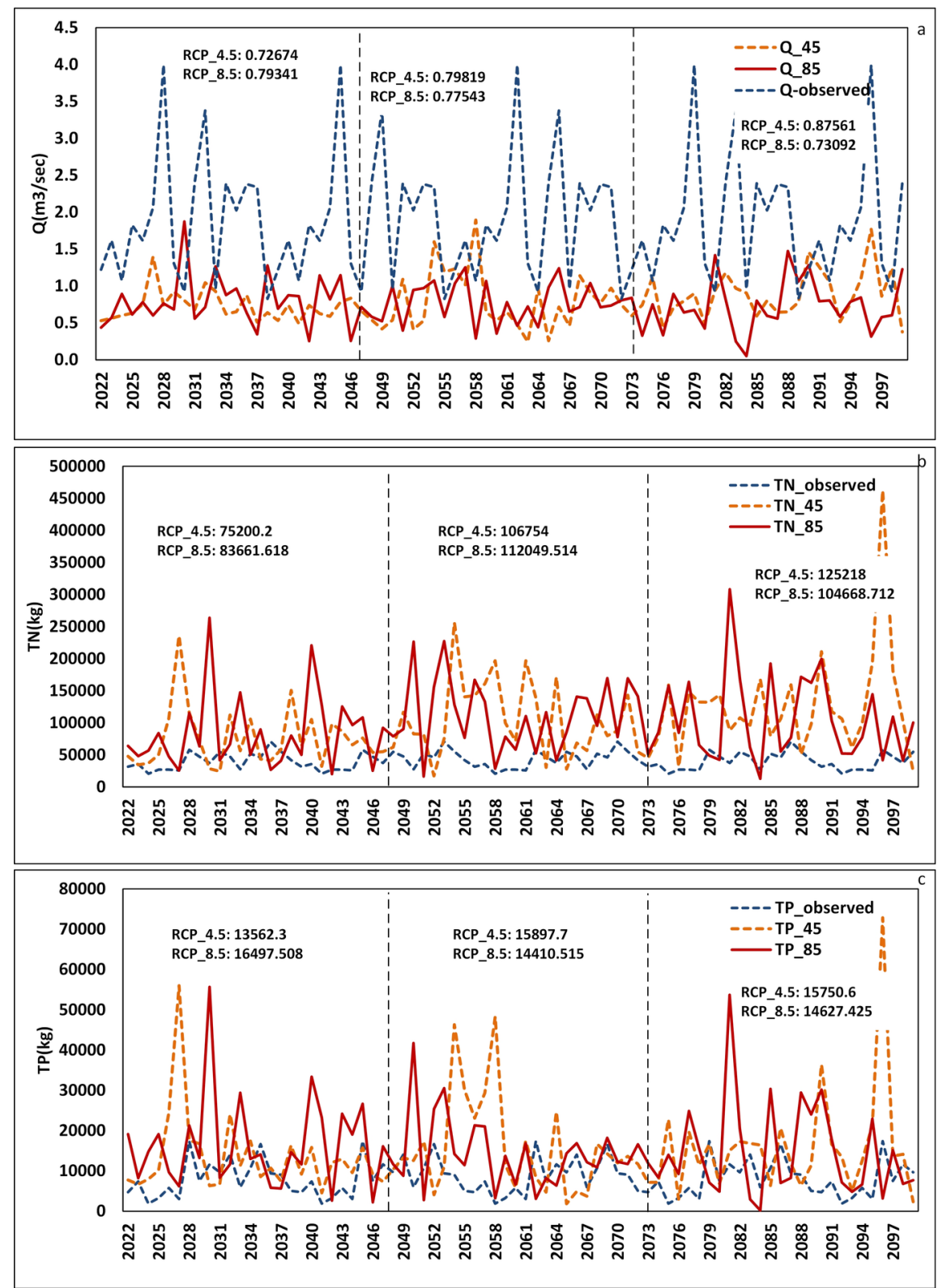

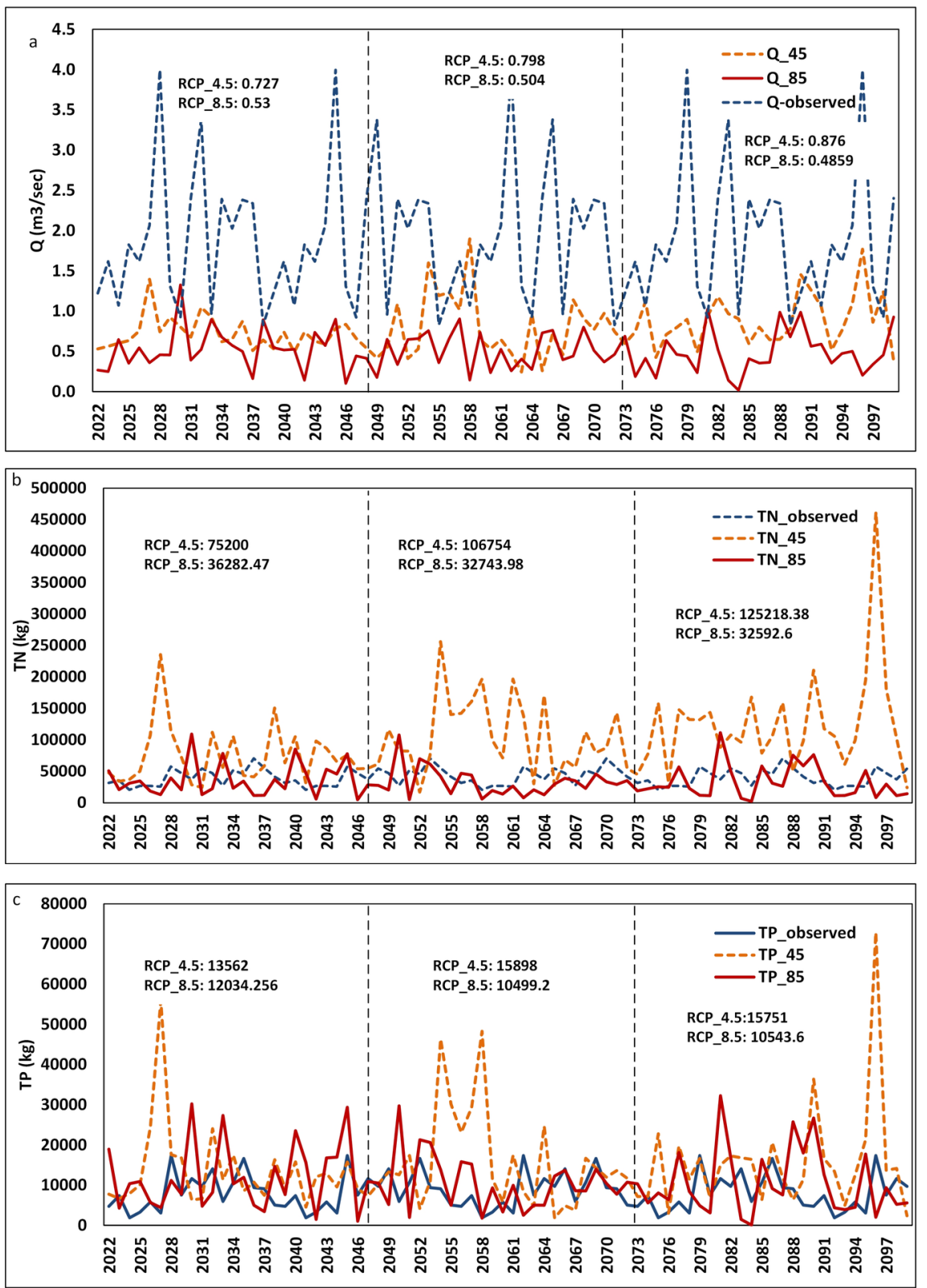